\title{
UPAYA MENINGKATKAN HASIL SALTO DEPAN GULUNG DENGAN MENGGUNAKAN MEDIA KOLAM BUSA PADA PESENAM JUNIOR PERSANI KOTA MEDAN
}

\author{
M. Syukur Zulbandi Sitepu \\ Alumni Prodi Pendidikan Olahraga, PPS Universitas Negeri Jakarta \\ zulbandisitepu@gmail.com
}

\begin{abstract}
Abstrak : Penelitian ini bertujuan untuk mengetahui peningkatan latihan teknik salto depan gulung dengan menggunakan media kolam busa pada pesenam Junior Persani Kota Medan. Yang menjadi sampel dalam penelitian ini adalah pesenam persani Kota Medan yang berjumlah 10 orang. Pesenam yang akan diberikan tindakan berupa bentuk latihan melalui program latihan dan penggunaan media. Metode yang dipakai dalam penelitian ini adalah Penelitian Tindakan Olahraga (Sport Action Research). Untuk memperoleh data dalam penelitian ini dilakukan tes hasil latihan di akhir siklus. Pelaksanaan penelitian ini dilaksanakan dengan I siklus selama 2 minggu dengan frekuensi latihan 3 kali dalam seminggu atau sebanyak 6 kali pertemuan dalam I siklus. Dalam 6 pertemuan diberikan pola latihan yaitu pola gerakan melangkah, pola gerakan dan pendaratan. Hasil penelitian menyimpulkan: (1) Dari pengamatan awal pesenam sebelum diberikan program latihan dan menggunakan media kolam busa diperoleh hasil saltodepan gulung kurang memuaskan(2) Dari hasil tes salto depan gulung setelah diberikan perlakuan pada siklus I yaitu latihan teknik dengan menggunakan media kolam busa melebihi dari target yang telah ditetapkan sebelumnya yaitu $80 \%$. Berdasarkan hasil analisis data tersebut dapat disimpulkan bahwa melalui latihan teknik menggunakan media kolam busa dapat meningkatkan teknik salto depan gulung dan memberikan pengaruh yang signifikan terhadap hasil salto depan gulung.
\end{abstract}

Kata Kunci : Salto Depan Gulung, Penelitian Tindakan Olahraga

\section{PENDAHULUAN}

Dalam senam artistik terdapat gerakan yang dapat dilakukan secara berkesinambungan seperti salto. Salto depan gulung merupakan, suatu gerakan dimana pesenam melakukan putaran di udara ke arah depan dengan putaran minimal $360^{\circ}$. Pelaksanaan salto depan gulung yang terdiri dari beberapa rangkaian gerak. Salto depan gulung adalah, melompat dengan dua kaki, tangan digerakkan memeluk lutut setelah lutut melekat kedada. Berikutnya tangan menciptakan dorongan kebawah. Setelah tba saat mendarat dengan posisi berdiri diatas matras.

Pelaksanaan salto depan gulung biasanya diawali dengan lari awalan, yang dapat dilakukan mulai tiga langkah, lima langkah, kemudian menolak kedua kaki ke atas. Segera setelah ke dua kaki meninggalkan lantai, kedua lengan diayun dari atas ke bawah untuk menciptakan momentum berputar ( circular ) yang dibantu dengan meninggikan pinggul dan menempatkan dagu ke dada sekaligus badan berputar ke depan. Selanjutnya saat diudara kaki ditekuk ke dada kepala menunduk sehingga ketika posisi badan terbalik badan sudah dalam keadaan membulat dan kaki dekat dengan dada dengan cara tangan menarik kedua lutut.

Ketika putaran berlanjut badan hampir menyelesaikan putarannya, kaki segera dibuka dan dijulurkan ke lantai dengan cepat untuk mendarat sebelum badan jatuh ke lantai. Usahakan mendarat dengan posisi kaki ditekuk sedikit dan kedua lengan diangkat ke depan atas.

Banyak terjadi kesalahan terutama pada saat mendarat dimana kaki melangkah, terduduk, bahkan ada yang terbanting pada saat melakukan salto depan gulung tersebut.

Adapun tujuan penelitian ini adalah untuk menemukan penjelasan dalam permasalahan yang dikemukakan diatas yaitu :Untuk mengetahui apakah latihan dengan menggunakan media kolam busa dapat meningkatkan hasil salto depan gulung pesenam junior Persani tahun 2012 ?

Menurut buku Petunjuk Lengkap GIMNASTIK Newton C Loken \& Robert J Willoughby Gimnastik, melibatkan beberapa jenis keterampilan yang paling mendasar, juga mencakup ketrampilan - ketrampilan yang telah ada. Permulaannya tidak begitu jelas, tetapi dapat diperkirakan tahun 2600 S.M, ketika bangsa Cina 
mengembangkan latihan - latihan yang menyerupai seperti Gimnastik.Namun perkembangan Gimnastik yang sesungguhnya mulai pada sejarah Romawi dan Yunani kuno.

Senam juga dapat diartikan sebagai bentuk latihan tubuh pada lantai atau pada alat yang dirancang untuk meningkatkan daya tahan, kekuatan, kelenturan, kelincahan, koordinasi, serta control tubuh.Sedikit demi sedikit senam terus berkembang sampai pada abad ke 18, dan oleh seorang bangsawan Jerman bernama Friederich Ludwig Jahn mengembangkan olahraga tersebut dan kemudian yang disebut - sebut sebagai bapak senam.

DISPORA ( 2004 : 3 ), dalam olahraga senam ada beberapa jenis senam yang diorganisir oleh FIG (Federation international de Gymnastique) yang dibagi menjadi 6 (enam) kelompok yaitu : 1. Senam Artistik, 2. Senam Ritmik Sportif, 3. Senam Akrobatik, 4. Senam Aerobik Sport, 5. Senam Trampolin, 6. Senam Umum.

Salto depan gulung merupakan suatu gerakan dimana seorang pesenam melakukan putaran di udara keaah depan dengan putaran minimal $360^{\circ}$. Mahendra (2000:53) mengungkakan bahwa: "Salto depan gulung adalah gerakan menggulung (berputar) di udara dengan jenis putaran yang berporos pada sumbu atau sering juga disebut putaran yang bersumbu transversal ( transverse aksis) ".

Menurut Mahendra (2000:54), kesalahan umum pada salto depan gulung adalah

1. Sudut naik tubuh pada saat menolak terlalu rendah sehingga arah tolakan kedepan.

2. Badan tidak membulat, kepala tidak ditekuk ke dalam, kaki tidak ditarik ke arah dada. Hal ini menyebabkan putaran salto melebar.

3. Terlalu cepat (dini) ketika membuka kaki sehingga mendarat dengan posisi terlentang atau jatuh duduk kebelakang.

4. Terlalu lambat membuka kaki, sehingga mendarat dengan posisi tersungkur atau dengan jongkok.

Berdasarkan teori di atas dibutuhkan kekuatan kaki yang mampu menolak setinggi tingginya.Selain untuk dapat menguasai teknik dan melakukan salto depan gulung yang baik, atlet harus mempunyai kondisi fisik yang baik. Seperti yang di ungkapkan Sajoto $(1988 ; 57)$ " kondisi fisik adalah salah satu persyaratan yang harus diperlukan dalam setiap usaha peningkatan prestasi seorang atlet bahkan, dapat dikatakan landasan titik tolak suatu awalan olahraga prestasi “. Salah satu unsur fisik tersebut meliputi kekuatan otot tungkai..

Harsono (1988:101) mengungkapkan bahwa ; " latihan adalah proses yang sistematis dari berlatih atau bekerja, yang dilakukan secara berulang - ulang, dengan demikian hari kian menambah jumlah beban latihan atau pekerjaannya ".
Di dalam latihan ada disebut latihan kondisi fisik, latihan kondisi fisik memegang peranan yang penting dalam peningkatan prestasi olahraga. Oleh karena itu, sebelum mengikuti suatu pertandingan / perlombaan atlet harus sudah berada dalam suatu kondisi fisik dan tingkat kebugaran (fitness) yang baik untuk menghadapi segala macam tekanan dan tingkatan intensitas tinggi yang akan dihadapinya dalam suat pertandingan / perlombaan.

Beberapa komponen latihan kondisi fisik seperti ; 1. Kecepatan (speed), 2. Daya tahan (endurance), 3. Kekuatan (strength), 4. Kelentukan (flexibility), 5. Kekuatan dan kecepatan (power), 6. Daya tahan dan kecepatan (stamina). 7. Kelincahan (agility).

Berdasarkan pendapat diatas dapat disimpulkan, bahwa latihan pada prinsipnya adalah memberikan tekanan fisik pada tubuh secara teratur, sistematik, berkesinambungan sehingga akan menambah kemampuan atlet yang pada akhirnya akan meningkatkan kemampuan atlet.

Sedangkan untuk melaksanakan suatu latihan diperlukan metode latihan yang dapat diartikan sebagai suatu cara untuk mencapai tujuan. Dengan demikian metode latihan adalah cara yang sistematis dan terencana yang berfungsi sebagai alat menyajikan program latihan untuk meningkatkan fungsi fisiologis, psikologis dan keterampilan gerak agar penampilan menjadi lebih baik pada suatu keterampilan tertentu.

Kemudian dalam upaya agar latihan efektif dan bermanfaat, latihan itu sendiri harus didasari dengan prinsip - prinsip latihan. Harsono (1988:102) mengungkapkan prinsip - prinsip latihan yaitu ; 1. Prinsip beban lebih, 2. Prinsip kekhususan atau spesialis, 3. Prinsip individualis, 4. Prinsip penggunaan beban secara bertahap, 5. Prinsip reverbilitas, 7. Prinsip pemulihan.

Dalam uraian dapat disimpulkan latihan merupakan, suatu kegiatan yang terencana dan sistematis untuk mempersiapkan kondisi fisik maupun teknik. Latihan kondisi fisik yang dilakukan secara cermat, berulang - ulang membuat kesegaran jasmani seseorang semakin meningkat, sehingga hal ini akan menyebabkan seseorang kian terampil, kuat dan efisien dalam gerakannya.

\section{METODE}

Metode yang digunakan adalah metode
Penelitian Tindakan Olahraga (PTO) ini
direncanakan dalam 1 siklus untuk melihat
peningkatan hasil salto depan gulung pesenam junior
persani kota Medan dengan penerapanm media
kolam busa.

Metode yang digunakan adalah metode peningkatan hasil salto depan gulung pesenam junior kolam busa. 
Teknik pengumpulan data dalam penelitian tindakan olahraga ini terdiri dari beberapa tahapsebagai berikut:

\section{Wawancara}

Dalam tahap ini kegiatan yang dilakukan oleh peneliti adalah melakukan wawancara kepada pesenam yang telah diberi perlakuan latihan metode bagian-bagian. Tahap ini dilakukan setelah semua program latihan dan siklus sudah terlaksana dengan baik dan benar sesuai dengan yang telah direncanakan. Pertanyaan-pertanyaan yang akan diberikan kepada pesenam diantaranya adalah yang berhubungan dengan hal yang dirasakan pesenam ketika melakukan metode bagian-bagian tersebut, apakah dia senang dengan metode bagian-bagian yang diberikan, bagaimana tanggapan pesenam terhadap metode bagian-bagian tersebut, dan apakah menurut atlet metode bagian-bagian ini dapat meningkatkan teknik salto depan gulung.

\section{Observasi}

Pada tahap ini kegiatan yang dilakukan adalah melakukan observasi terhadap tindakan yang telah diberikan yaitu latihan metode bagian-bagian salto depan gulung. Pada tahap ini juga dilakukan penilaian terhadap hasil latihan yang telah diberikan menggunakan lembar observasi atau lembar penilaian hasil latihan metode bagian-bagian yang telah disusun untuk mengetahui apakah sudah terjadi peningkatan atau tidak. Penilaian menggunakan lembar observasi ini dilakukan setiap pertemuan dalam latihan. Peneliti yang bertugas sebagai pengamat mengisi lembar observasi untuk melihat apakah proses latihan metode bagian-bagian sudah terlaksana sesuai program latihan ketika tindakan dilakukan. Hal serupa juga dilakukan oleh kolaboratif pada saat melakukan observasi terhadap peneliti tentang materi yang disampaikan dalam latihan.

\section{Tes}

Pada tahap ini kegiatan yang akan dilakukan oleh peneliti adalah melakukan tes kepada pesenam terhadap hasil latihan metode bagian-bagian yang dilakukan oleh pesenam selama 2 minggu yang terdiri dari 1 siklus, Kegiatan lain yang dilakukan pada tahap ini adalah membuat lembar observasi atau penilaian terhadap tes yang akan dilakukan. Peneliti sekaligus bertindak sebagai pengamat dalam tahap ini.

Orang coba yang dipergunakan dalam penelitian ini adalah pesenam junior Persani Kota Medan tahun 2012 yang berjumlah 10 orang. Sesuai dengan jenis penelitian ini, yaitu penelitian tindakan olahraga maka penelitian terdiri dari beberapa tahap yang berupa siklus sebagai berikut :

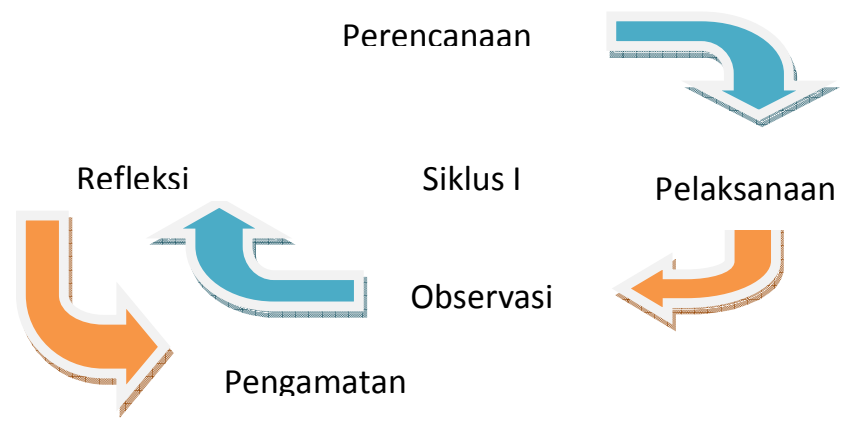

Gambar 1. Skema Siklus Dalam Penelitian Tindakan (Agus kristiyanto)

\section{Siklus I}

\section{Tahap Perencanaan Tindakan (Alternatif Pemecahan I)}

Pada tahap ini kegiatan yang dilakukan adalah merencanakan tindakan berdasarkan permasalahan yang ada yaitu dengan membuat program latihan yang disesuaikan dengan kesulitan pesenam pada saat melakukan tekniksalto depan Gulung. Dan alternatif tindakan yang direncanakan akan diberikan kepada pesenam junior Persani kota Medan tahun 2012 yaitu memberikan teknik salto depan gulung, Indikator keberhasilan $100 \%$, jika tercapai penelitian sampai siklus 1

\section{Tahap Pelaksanaan Tindakan I}

Setelah perencanaan disusun maka dilakukan tindakan terhadap pesenam yaitu dengan memberikan program latihan tersebut untuk meningkatkan teknik salto depan gulung yang dilakukan oleh peneliti bertindak sebagai pelatih serta pelatih pesenam tersebut dan juga bertindak sebagai penilai pada teknik salto depan gulung yang dilakukan merupakan pelaksana program latihan yang telah disusun. Pelaksanaannya diterangkan seperti dibawah ini: 
1. Seluruh Pesenam dikumpulkan di Gedung Senam Prof. Drs. Jepta Hutabarat, kemudian dilaksanakan proses latihan

2. Kemudian pelatih memberitahukan dan memberi contoh teknik yang benar kepada pesenam dan kemudian pelatih menginstruksikan kepada pesenam untuk mempraktekkan lagi teknik Salto Depan Gulung ke media yang telah ada yaitu Kolam Busa.

3. Setelah pelatih melihat gerakan pesenam pelatih menginstruksikan untuk melakukan tes dan sambil dilakukan pengambilan data untuk melihat apakah ada peran pemanfaatan pelatih menggunakan gaya melatih secara otoriter. Waktu yang dibutuhkan 80 menit.

\section{Observasi dan interpretasi I}

Tahap ini dilaksanakan bersamaan dengan pelaksanaan tindakan. Tahapan ini difokuskan pada pengamatan terhadap kesulitan-kesulitan Pesenam junior Persani kota Medan tahun 2012 yang menyebabkan rendahnya bentuk gerakan pesenam pada teknik yang diajarkan serta aktivitas pesenam selama proses latihan berlangsung. Pada tahapan ini peneliti dapat melihat tinggi rendahnya kemampuan pesenam melalui teknik Salto depan Gulung, yaitu pada saat pesenam melakukan gerakan tersebut.

\section{Analisis dan Refleksi I}

Hasil yang didapat dari tahap tindakan dan observasi yang dikumpulkan dan dianalisis pada tahap ini, sehingga dapat disimpulkan dari tindakan yang dilakukan dari pengamatan pelatih terhadap teknikSalto Depan Gulug yang dilakukan dari hasil tes.jika pada siklus 1 teknik pesenam sudah meningkat maka dihentikan dan jika belum dilanjutkan ke siklus 2.

Dalam instrumen penelitian terdapat Variabel terikat yang akan dianalisis adalah hasil teknik Salto Depan Gulung pada pesenam junior Persani Medan. Penelitian ini bertujuan untuk mengetahui kemampuan pesenam dalam melakukan Salto Depan Gulung. Maka untuk dapat mengumpulkan data yang diperlukan dalam penelitian ini, Alat dan Perlengkapan yang diperlukan dalam tes ini adalah :

a. Lembar observasi :

1. Lembar observasi pesenam

2. Lembar observasi pelatih

b. Kamera digital

c. Handycam

Cara menilai senam lantai :
Menilai senam lantai biasaja menggunakan beberapa cara namun karena sifatnya yang subjektif, maka penilaian senam harus didasarkan pada peraturan serta patokan yang cukup jelas.

Dalam kejuaraan yang resmi, penilaian senam didasarkan pada:

- $\quad$ Tingkat kesulitan

- Persyaratan khusus

- Nilai bonus

- Penampilan / pelaksanaan

d. Kesalahan didalam salto depan gulung:

Jika pesenam melakukan kesalahan, wasit akan memotong atau mengurangi nilainya dari dasarteknik tersebut. Tergantung dari kesalahannya, wasit akan memotong berdasarkan ketentuan

e. Dasar Penilaian Salto Depan Gulung.

Penilaian salto depan gulung yang dilakukan pesenam junior PERSANI Medan tahun 2012 dapat dilihat sebagai berikut :

- $\quad$ Nilai Dasar Salto Depan Gulung 10.00

- Pengurangan nilai dapat dilihat dari pelaksanaan salto depan gulung tersebut yang diambil berdasarkan lampiran.

Menentukan Nilai Akhir Pesenam dalam suatu kejuaraan,biasanya pesenam dinilai oleh beberapa orang wasit, bisa terdiri dari 4 sampai 6 orang wasit. Untuk menentukan nilai akhir seorang pesenam peraturannya adalah, nilai tertinggi dan terendahnya dicoret, lalu nilai tengahnya dirata - ratakan.Tabel penilaian akhir pesenam dapat dilihat dilampiran.

Analisa data yang dilakukan terdiri dari beberapa tahap diantaranya:

1. Reduksi Data

Proses reduksi data dilakukan dengan cara menyeleksi, menyederhanakan dan mentranformasikan data yang telah disajikan dalam transkip catatan lapangan. Kegiatan reduksi data ini bertujuan untuk melihat kesalahan atau kekurangan atlet dalam pelaksanaan tes dan tindakan apa yang dilakukan untuk perbaikan tersebut.

2. Paparan Data

Dalam kegiatan ini data yang diperoleh dari hasil latihan atletdipaparkan dengan menggunakan rumus yang sudah ditetapkan. Untuk mengetahui persentase kemampuan atlet digunakan rumus:

$$
\mathrm{PPH}=\frac{B}{N} \mathrm{X} 100 \%
$$

Keterangan :

PPH : Persentase Penilaian Hasil

B : Skor yang diperoleh

$\mathrm{N} \quad$ : Skor total maksimal (32) 
Tabel 1. Persentase Ketuntasan Latihan

\begin{tabular}{|c|c|c|}
\hline Nilai & Kategori & Keterangan \\
\hline $70-80 \%$ & Lulus & Latihan Berhasil \\
\hline $46-69 \%$ & Tidak Lulus & Latihan Tidak Berhasil \\
\hline $30-45 \%$ & Tidak Lulus & Latihan Tidak Berhasil \\
\hline$<29 \%$ & Tidak Lulus & Latihan Tidak Berhasil \\
\hline
\end{tabular}

Dari uraian di atas maka akan dapat diketahui atlet yang belum tuntas dalam latihan secara individu. Berdasarkan ketuntasan latihan, jika latihan tercapai 70\% maka ketuntasan latihan telah tercapai Nurkencana (1986:80). Rumus PKK (Persentase Kriteria Ketuntasan) :

$\mathrm{PKK}=\frac{\text { banyak atlet } \mathrm{yang} \mathrm{kkm} \geq 70 \%}{\text { banyak atlet keseluruhan }}$

\section{HASIL DAN PEMBAHASAN}

Berdasarkan hasil tes salto depan gulung di gedung senam Prof. Drs. Jepta Hutabarat. Permasalahan yang dialami oleh pesenam tersebut adalah kurangnya tolakan kaki dan putaran badan yang benar, sehingga pada saat tes salto depan gulung pesenam melakukan teknik yang tidak tepat. Mencermati masalah tersebut, maka diberikan suatu bentuk latihan dengan menggunakan media kolam busa. Pelaksanaan dari bentuk latihan tersebut adalah dilakukan selama 6 pertemuan, dalam pertemuan terdiri dari 3 bentuk latihan yaitu :

1. Awalan : 3 langkah, 5 langkah

2. Perlakuan salto depan : menganyun kedua tangan, meninggikan pinggul, kaki ditekuk ke dada, kepala menunduk.

3. Pendaratan : kedua kaki ditekuk, kedua lengan diangkat ke atas

Hasil dari siklus I pesenam tersebut telah mencapai target keberhasilan latihan yang telah ditetapkan yaitu $80 \%$, dapat dilihat bahwa hasil latihan pesenam dari awal sampai dilakukannya siklus terjadi peningkatan, maka dapat disimpulkan bahwa dengan menggunakan media kolam busa memberikan pengaruh yg signifikan terhadap meningkatkan hasil salto depan gulung pesenam. Setelah diberikan bahwa seluruh pesenam meningkat bahkan $100 \%$

Berdasarkan deskripsi data penelitan, maka dalam penelitian ini didapatkan hal sebagai berikut :

Setelah diberikan perlakuan pada siklus I sebanyak 6 kali pertemuan, pesenam diberikan tes hasil latihan yaitu tes salto depan gulung yang kemudian diperoleh hasil 10 pesenam tersebut telah mencapai tingkat keberhasilan latihan atau sesuai dengan target yang telah ditetapkan yaitu $80 \%$. Hal ini sesuai dengan hasl observasi yang dilakukan oleh peneliti disetiap pertemuan selama dilapangan, dimana selama proses observasi dilakukan pesenam melakukan gerakan dengan baik dan benar sesuai dengan instruksi yang diberikan oleh peneliti.

Salah satu faktor yang mendukung adalah pesenam tersebut bisa mengikuti gerakan dari peneliti yang bertindak sebagai pelatih tersebut, hal ini terbukti pada saat pesenam diberikan bentuk latihan pada saat pertemuan pertama sampai dengan pertemuan ke enam, tanpa harus memberikan contoh secara berulang - ulang, pesenam telah mampu melakukan geraan sesuai dengan yang diharapkan. Berdasarkan hasil wawancara peneliti kepada pesenam, pesenam sangat senang dengan sistem latihan yang menggunaka media kolam busa untuk meningkatkan hasil salto mereka.

Hal itu terbukti dari pengamatan pertama yang diperoleh dari pelatih dan peneliti, dimana sebelum pesenam diberikan perlakuan dengan menggunakan media kolam busa dan program latihan pesenam belum dapat melakukan teknik dengan baik dan benar. Setelah diberikan perlakuan maka dilakukan tes akhir latihan yaitu salto depan gulung. Pesenam sudah mampu melakukan teknik salto depan gulung dengan baik dengan hasil tes pesenam yaitu Vicky (7.75), Alif (7.82), Moses (7.72), Kevin (8), Zona (7.87), Patrick (7.90), Dimas (8.01), Nicholas (8.01), Johanes (8.09), Desmon (7.93).

Dari analisis data yang telah dilakukan dapat dismpulkan bahwa dengan menggunakan media kolam busa dapat meningkatkan hasil salto depan gulung dan memberikan pengaruh terhadap hasil latihan tersebut. Dimana terlihat hasil latihan pesenam pada siklus I dan keberhasilan dalam latihan telah tercapai sesuai dengan target yang telah ditetapkan. Pada saat diberikan perlakuan pada siklus I peneliti menemukan beberapa kesulitan yang dialami oleh pesenam pada saat dalam proses latihan diantaranya adalah :

1. Masih ada pesenam yang salah melakukan gerakan teknik yang sudah diberikan.

2. Untuk menyelesaikan masalah yang terjadi pada pertemuan tersebut maka peneliti bekerja sama dengan pelatih dan memberikan serta menjelaskan teknik yang akan diberikan agar 
pesenam dapat melakukan sesuai dengan apa yang diberikan.

Dari tes hasil analisis yang dilakukan dapat disimpulkan bahwa telah terjadi peningkatan hasil latihan pesenam. Hal ini sesuai dengan observasi yang dilakukan oleh peneliti disetiap pertemuan selama dilapangan, dimana selama proses observasi dilakukan pesenam melakukan gerakan dengan baik dan benar sesuai dengan instruksi yang diberikan oleh peneliti. Berdasarkan hasil wawancara peneliti terhadap pesenam juga mendapat respon positif karena mereka senang dengan media yang digunakan.untuk melihat peningkatan yang telah mereka capai.

Tujuan dari penguasaan teknik bertujuan untuk memberikan hasil yang terbaik dalam pertandingan dan sebagai peningkat prestasi.Hal tersebut terbukti dari awal yang diperoleh oleh peneliti, dimana sebelum pesenam diberikan perlakuan dengan menggunakan media kolam busa hasil yang diperoleh masi kurang baik. Setelah diberikan perlakuan pesenam sudah mampu melakukan teknik salto depan gulung dengan benar. Ini berarti dengan menggunakan media kolam busa dapat meningkatkan hasil teknik salto depan gulung para pesenam

\section{KESIMPULAN}

Berdasarkan dari pengamatan awal pesenam sebelum menggunakan media kolam busa, teknik salto depan gulung mereka masih banyak kesalahan. Dari hasil tes salto depan gulung setelah diberikan perlakuan pada siklus I yaitu latihan teknik dengan menggunakan media kolam busa mencapai target yang telah ditetapkan sebelumnya yaitu $70 \%$. Berdasarkan hasil analisis data tersebut dapat disimpulkan bahwamenggunakan media kolam busa dapat meningkatkan teknik salto depan gulung dan memberikan pengaruh yang signifikan terhadap hasil salto depan gulung para pesenam.

Sebagai saran yang dapat diberikan oleh peneliti adalah sebagai berikut :

1. Disarankan kepada Pelatih senam untuk dapat memberikan program latihan yang berbeda terhadap pengaruh teknik salto depan gulung.

2. Kepada teman - teman mahasiswa FIK UNIMED agar dapat mencoba melakukan Penelitian Tindakan Olahraga ( PTO ) dengan melalui bentuk - bentuk latihan teknik lainnya.

3. Kepada para pengajar atau pendidik khususnya Guru Penjas, diharapkan dapat memberikan program latihan yang baik sesuai dengan cabang olahraga yang diajarkan

\section{REFERENSI}

Dispora. 2004. Petunjuk Olahraga Senam. Jakarta

Loken, Newton C dan Willoughby. 1986. Petunjuk Lengkap Gymnastik. Membahas Program Latihan dan Teknik. Jakarta : Dahara Prize

Mahendra. 2000. Senam. Jakarta : Departemen Pendidikan Nasional. Direktorat

Newton C dan Robert j. 1986 Gimnastik. 